\title{
Plants and Animals in Brazilian Literature: Introduction
}

\author{
MARIA ESTHER MACIEL \\ Universidad Federal de Minas Gerais \\ PATRÍCIA VIEIRA \\ Georgetown University \\ Centro de Estudos Sociais da Universidade de Coimbra
}

Recent reflections on non-human living beings have led contemporary thinkers to brave new paths in a variety of fields, from the natural sciences to philosophy and literature. This has resulted in a reconfiguration of concepts such as nature and culture, as well as of our understanding of the human, of humanism, and of humanity. Ethnographic studies such as those of Eduardo Viveiros de Castro and Philippe Descola have highlighted the contributions of Amerindian peoples to this novel approach to non-humans; they have also shown that "what some call 'nature' might be the 'culture' of others" (Viveiros de Castro 53). We now know that the interconnection of plants, animals and humans has always been part of the mythological, artistic", and literary repertoire of indigenous cultures from Brazil and from the rest of the Americas, a worldview that was progressively erased by the process of colonization, starting in the sixteenth century.

Still, plants and animals featured prominently in considerations of the New World from the arrival of the first colonizers onward. The territory that is now Brazil was perceived as a bountiful natural landscape that contrasted sharply with the environment of Europe. The first explorers and settlers admired the region's lush forests and wide variety of vegetation and fauna, much of which was hitherto unknown in the Old Continent. From Pêro Vaz de Caminha's Carta de achamento (1500), the first written document on the region, through the writings of historian Pêro de Magalhães Gândavo in the second half of the sixteenth 
century, to Simão de Vasconcelos's seventeenth-century Notícias Curiosas e Necessárias das Cousas do Brazil, to name only a few, Europeans made much of the area's abundant flora and fauna, often describing them in detail.

Caminha speaks of "arvoredos [...] mui muitos e grandes, e de infinitas espécies," and adds, "não duvido que por esse sertão haja muitas aves!” Gândavo extols the Brazilian vegetables and fruits, such as manioc, banana, pineapple, and cashew nuts, as well as animals like the capybara, the tapir, and the armadillo, whose meat is both tasty and healthful. Vasconcelos later devotes a large section of his book to the virtues of various Brazilian plants, and he concludes that the region meets all the criteria for being prosperous: good climate, waters, and vegetation, together with an abundance of fish and other animals. It is telling that the very name of the nation goes back to a plant, the Brazilwood or, in Portuguese, pau-brasil, which was plentiful in the Northeast of the country and was used both as timber and to make red dye.

As for fauna, one should note the presence of fantastic elements in the descriptions made by European writers from the sixteenth century. Using rudimentary systems of classification and astonished by the radical alterity of New World animals, they were forced to resort to their imagination, as well to books on natural history and medieval encyclopedias to describe the strange beings they found in Brazil. Their depictions of parrots, snakes, skunks, iguanas, monkeys, and so on were a combination of an effort at taxonomic classification and imaginary, sometimes absurd details, as historian Afonso d'Escragnolle Taunay (1876-1958) pointed out in Zoologia Fantástica do Brasil (1934) and in Monstros e Monstrengos do Brasil (1937).

The colonial depiction of Brazilian nature as a cornucopia would shape the country's identity for years to come. The vastness of the land and its environmental richness were some of the arguments adduced to support the region's claim of independence from Portugal in the 1820s (McNee 3). In the post-independence context, nation and environment continued to be inextricably linked. On the one hand, the exuberance and wealth of Brazilian flora and fauna bolstered the young country's political power, as politicians and theorists connected the force of nature metaphorically to the state. It was common, for instance, for images of the emperor to contain tropical trees and fruits to reinforce the connection between nation and nature (Pádua 124). On the other hand, Brazil's lush landscapes served as a separating marker, distinguishing the region 
from Europe, in the same way that intellectuals sought to forge a uniquely Brazilian culture, disparate from that of the former colonizers. The paintings of Tarsila do Amaral, for instance, with their stylized representations of local plants and animals, offer powerful images of a natural environment radically different from that of the Old World.

If Brazil's lush environment has long been at the root of its political and cultural identity, the country's literary production has reflected the national indebtedness to nature. José de Alencar's foundational novel Iracema (1865) mentions numerous local plants and animals associated with the narrative's heroine, who herself stands in metonymically for the land of Brazil. The first two stanzas of "Canção do Exílio, written in 1843 by Alencar's contemporary Gonçalves Dias, provide a well-known literary example of the imbrication of nation and nature in the Brazilian context. Living far from his homeland (he penned the poem while studying at the Universidade de Coimbra), Dias compares European landscapes to the prodigal environment of Brazil:

Minha terra tem palmeiras,

Onde canta o Sabiá;

As aves, que aqui gorjeiam,

Não gorjeiam como lá.

Nosso céu tem mais estrelas,

Nossas várzeas têm mais flores,

Nossos bosques têm mais vida,

Nossa vida mais amores.

"Song of Exile" is an integral part of the Brazilian literary canon, and several subsequent writers would rework and reinterpret it. The poem revolves around a simple opposition between here and there, and most readers have interpreted this to refer to the differences between Portugal and Brazil. Plants and animals abound "there"-note the repetition of "more" in all the lines of the second stanza - and are in general lovelier than their European counterparts. From this already ideologically charged statement about the excellence of Brazilian nature, the poet deftly moves on to assert the advantages of life in his homeland: "Nossa vida mais amores." Part of the nationalistic literature that emerged in the 
aftermath of Brazilian independence from Portugal in 1822, the poem nevertheless goes back to a common trope of writings from the colonial period. It sings the praises of life in Brazil and maintains its superiority tied to the country's lavish and charming fauna and flora.

Nationalism and nature continue to be linked in Brazilian literature throughout the twentieth century. Modernist writers have drawn from the environment to reconfigure national letters, which they considered to be overly dependent on foreign cultural and literary models. Mário de Andrade's Macunaíma (1928) and Raul Bopp's Cobra Norato (1931), for instance, draw upon Amazonian flora, fauna, and folkloric traditions as a source of inspiration. Both writers turned to the Amazon as an emblematic Brazilian landscape that distinguishes the country from other European and North American nations. It is also worth mentioning Wilson Bueno, a more contemporary writer who reinvents the legacy of European chroniclers and adds to it the Amerindian imaginary in his Jardim Zoológico (1999). The animals that Bueno depicts are transnational and transcultural, and they can therefore be understood as metaphors for a hybrid cultural heritage that is in tune with late twentieth-century Brazilian national identity.

While Brazil's environment has left a lasting imprint on the country's literary output, not all texts that revolve around flora and fauna are linked to an explicit political agenda. Perhaps because the region has historically been understood through the lens of its natural landscapes, the environment crops up in the nation's letters in myriad different ways. The work of writers such as Graciliano Ramos, João Guimarães Rosa, Carlos Drummond de Andrade and Clarice Lispector inaugurates a new take on plants and animals in Brazilian literature. These authors reflect upon the relationship between humans and non-humans and refuse the appropriation of plants and animals as raw materials for humanity's use and consumption. From the end of the twentieth century onward, a new generation of Brazilian writers, including Nuno Ramos, Sérgio Medeiros, Josely Vianna Baptista, and Astrid Cabral, to mention only a few, have depicted flora and fauna in their texts by taking ethical and ecological issues into account. Their writings appear against the background of large-scale environmental catastrophes, the extinction of numerous species, the decimation of native Brazilians and the corresponding appropriation of their ancestral lands, and the 
expansion of industrial agriculture and farming, among many other ecological problems.

The articles included in this special issue reflect on the variety of approaches to plants and animals in Brazilian literature from the Amerindian worldview to more recent writings. In the first text, Sérgio Medeiros discusses three myths of indigenous literature, where humans and plants engage in sexual intercourse. Medeiros's literary work, which brings together elements of Amerindian cosmogonies, avant-garde poetics and Zen Buddhist poetry is then the focus of Malcolm McNee's essay, where he analyzes interspecies relations and poetic plurality from a post-humanist point of view.

Maria Esther Maciel concentrates on the portrayal of dogs in the work of Joaquim Maria Machado de Assis and Clarice Lispector. Canine literature is also the topic of Fernanda Coutinho's essay, as she discusses the character Baleia in Graciliano Ramos's Vidas Secas. Patrícia Vieira returns to the work of Clarice Lispector, analyzing the transformative encounter of humans with both plants and animals. Non-human temporality is the topic of Gabriel Giorgi's essay, which considers Nuno Ramos's oeuvre and the ways in which it challenges traditional notions of human subjectivity.

We hope that these interdisciplinary analyzes of Brazilian writings on plants and animals will contribute to the contemporary debate on the complex relationship between humans and non-human beings. And, in turn, that an ecocritical viewpoint will open new avenues for the interpretation of Brazil's multifaceted literary tradition.

\section{Works Cited}

Alencar, José de. Iracema. Garnier, 1865.

Andrade, Mário de. Macunaíma. 1928.

Bopp, Raul. Cobra Norato. Ferraz, 1931.

Bueno, Wilson. Jardim Zoológico. Iluminuras, 1999.

Caminha, Pêro Vaz de. "A Carta de Pêro Vaz de Caminha." Público, 5 Mar.

2014, www.publico.pt/culturaipsilon/noticia/a-carta-de-pero-vaz-decaminha-1627013. Accessed 27 Apr. 2016. 
Escragnolle-Taunay, Afonso de. Monstros e monstrengos do Brasil: ensaio sobre a zoologia fantástica brasileira nos séculos XVII e XVIII. Companhia das Letras, 1998.

—. Zoologia fantástica do Brasil (séculos XVI e XVII). U de São Paulo, 1999.

Gândavo. Pêro de Magalhães. História da província Santa Cruz que vulgarmente chamamos Brasil. João Lopes, 1576.

McNee, Malcolm K. The Environmental Imaginary in Brazilian Poetry and Art. Palgrave MacMillan, 2014.

Pádua, José Augusto. Natureza e projeto nacional: as origens da ecologia política no Brasil. Instituto Universitário de Pesquisas do Rio de Janeiro e Sociedade Brasileira de Instrução, 1986.

Ramos, Graciliano. Vidas secas. José Olympio, 1938.

Vasconcelos, Simão de. Notícias curiosas e necessárias das cousas do Brasil. João de Costa, 1668.

Viveiros de Castro, Eduardo. Metafísicas Canibais. Cosac Naify, 2015. 